\title{
Pengukuran Skala Kecemasan Sosial pada Pengguna Media Sosial Berusia Dewasa Awal
}

\author{
Fitria Herman ${ }^{1}$, Alwin M. Sambul ${ }^{2}$, Sary D. E. Paturusi ${ }^{3}$ \\ Teknik Informatika Universitas Sam Ratulangi. Manado, Jl. Kampus Unsrat Bahu, Manado 95115 \\ 13021106131@student.unsrat.ac.id ${ }^{1}$, asambul@unsrat.ac.id ${ }^{2}$, sarypaturusi@unsrat.ac.id ${ }^{3}$
}

\begin{abstract}
Abstrak - Media sosial sedikit demi sedikit membawa kita ke suatu pola budaya yang baru yang menentukan pola pikir kita. Media sosial dapat membuat kita mengurangi interaksi langsung dengan orang lain. Saat ini Facebook dan Instagram merupakan media sosial paling populer di kalangan anak muda, tidak hanya sebagai tempat memperoleh informasi tetapi sudah menjadi gaya hidup. Facebook dan Instagram juga memiliki perbedaan dari segi fitur, selain itu ada perbedaan dalam hal fitur yang berkaitan dengan empat dimensi pada instrumen SAS-SMU. Penelitian dengan judul "Pengukuran Skala Kecemasan Sosial pada Pengguna Media Sosial Berusia Dewasa Awal" memiliki rumusan masalah bagaimana mengukur skala tingkat kecemasan sosial pengguna Facebook dan Instagram dan bagaimana perbandingan kecemasan sosial pada kedua media sosial Facebook dan Instagram. Tujuan penelitian ini adalah untuk mengukur skala tingkat kecemasan sosial pengguna Facebook dan Instagram dan untuk mengetahui perbandingan kecemasan sosial pada kedua media sosial pengguna Facebook dan Instagram. Penelitian ini menggunakan metode pengumpulan data SAS-SMU untuk mengukur tingkat kecemasan sosial seseorang. Berdasarkan analisa data yang dilakukan, diperoleh kesimpulan bahwa data menunjukkan ada sedikit perbedaan antara pengguna Facebook dan pengguna Instagram. Namun dari hasil analisis menggunakan instrumen Social Anxiety Scales for Social Media User (SAS-SMU), tingkat kecemasan sosial pengguna Facebook dan Instagram sama dan tidak ada perbedaan.
\end{abstract}

Kata kunci : Pengukuran skala kecemasan media sosial

\section{PENDAHULUAN}

Kecemasan sosial dapat membatasi interaksi seseorang dengan teman sebaya, atau memiliki pergaulan yang terbatas, dan menunjukkan keterampilan sosial yang buruk sehingga dapat mengganggu fungsi sosial mereka. Media sosial dianggap tidak baik bagi orang-orang yang sering membandingkan dirinya dengan orang lain, karena berisiko lebih besar menderita depresi dan kecemasan sosial.

Saat ini Facebook dan Instagram bagi manusia merupakan hal yang penting tidak hanya sebagai tempat memperoleh informasi yang menarik tetapi juga sudah menjadi gaya hidup. Media sosial sedikit demi sedikit membawa kita kesuatu pola budaya yang baru dan menentukan pola pikir kita. Banyak faktor yang mempengaruhi seseorang aktif di Facebook dan Instagram, salah satunya tidak memiliki kepercayaan diri untuk bergaul karena keberadaanya tidak diterima oleh lingkungan sekitarnya.

Facebook mencatat pengguna aktif di Indonesia mengalami pertumbuhan. Dalam setahun terakhir peningkatannya mencapai $40 \%$. Tiap hari rata-rata ada 65 juta pengguna di Indonesia. Sebanyak 97\% pengguna mengakses media sosial terbesar di dunia melalui smartphone [1]. Tidak hanya Facebook, Instagram juga akhir-akhir ini menjadi jejaring sosial populer di Indonesia. Indonesia menjadi Negara dengan pengguna Instagram terbesar se-Asia Pasifik. Dari 700 pengguna aktif bulanan alias monthly active user (MUA) yang diraup Instagram secara global, 45 juta diantaranya berasal dari Indonesia [2].

Facebook dan Instagram juga memiliki perbedaan dari segi fitur, selain itu Facebook dan Instagram juga ada perbedaan dalam hal fitur yang berkaitan dengan empat dimensi pada instrumen SAS-SMU.

\section{LANDASAN TEORI}

\section{II.1 Pengukuran}

Pengukuran adalah pengumpulan data kegiatan yang dilakukan untuk memberikan angka-angka untuk menentukan fakta kuantitatif sesuai dengan objek yang diukur.

\section{2 Media Sosial}

Media sosial adalah sarana komunikasi masa kini, selain itu media sosial juga membawa dampak yang sangat signifikan dalam cara komunikasi pada sisi kehidupan masyarakat.

\section{II.2.1 Facebook}

Facebook adalah situs jaringan sosial populer yang memungkinkan pengguna terdaftar untuk membuat profil, upload foto dan video, mengirim pesan dan tetap berhubungan dengan teman, keluarga dan kolega. Fitur yang ditawarkan Facebook sebagai situs jejaring sosial membuat banyak orang menggunakannya termasuk menyediakan 37 bahasa berbeda [3].

Menurut data (We Are Social,2015) pengguna Facebook di Indonesia semakin pesat dan didominasi kalangan anak muda, pengguna Facebook terbanyak 35 juta berusia 20-29 tahun dengan jumlah pengguna berjenis kelamin laki-laki sebanyak $60 \%$ dan perempuan $40 \%$. Disusul dengan pengguna nomor dua terbanyak yaitu 26 juta berusia 13-19 tahun dengan jumlah pengguna berjenis kelamin laki-laki $50 \%$ dan perempuan 50\%. (liputan6,2017) pengguna Facebook di Indonesia semakin meningkat dari tahun ke tahun, dari data kuartal kedua tahun 2017 (per juli), jumlah pengguna Facebook di Indonesia mencapai 115 juta user. jumlah pertemanan orang Indonesia lebih dari dua kali ratarata pertemanan yang dibuat oleh pengguna global, sehingga Indonesia masuk dalam deretan nomor tiga Negara teratas dengan jumlah teman tertinggi [1]. 
Tabel 1. pengguna Instagram seluruh dunia 2017

700 Juta pengguna Instagram di seluruh dunia

\begin{tabular}{|c|c|}
\hline Perempuan & Laki-laki \\
\hline $60 \%$ & 40 \\
\hline
\end{tabular}

\section{II.2.2 Instagram}

Instagram resmi lahir dan dirilis untuk platform IOS pada tanggal 6 oktober 2010. Salah satu pendirinya adalah sosok bernama Kevin Systrom, lulusan Stanford University yang kini juga menjadi CEO aplikasi Instagram. Instagram dipandang sebagai jejaring sosial generasi baru yang berfokus pada foto. Indonesia adalah salah satu Negara dengan jumlah pengguna Instagram terbanyak dengan $89 \%$ Instagrammers yang berusia 18-34 tahun mengakses Instagram setidaknnya seminggu sekali. Pengguna Instagram di Indonesia mayoritas anak muda dengan ratarata berusia 18-24 tahun sebanyak 59\%, usia 34-45 tahun $30 \%$, dan yang berusia 34-44 tahun 11\%. Selain itu pengguna Instagram berdasarkan jenis kelamin perempuan yang paling aktif sebanyak 63\% dan laki-laki 37\% [4]. (Okezone Techno,2016)

Dari hasil survey Monthly Active Users pengguna Instagram seluruh dunia di tahun 2017 dapat dilihat pada Tabel 1 pengguna Instagram mencapai 700 juta pengguna. Dari 700 juta pengguna berdasarkan jenis kelamin perempuan pengguna paling banyak menggunakan Instagram, dengan jumlah $60 \%$ dan laki-laki $40 \%$ pengguna Instagram diseluruh dunia.

\section{II.3 Dewasa Awal}

Menurut (Hurlock, 1996) masa dewasa awal dimulai pada umur 18 tahun sampai kira-kira umur 40 tahun. Saat perubahan-perubahan fisik dan psikologis yang menyertai berkurangnya kemampuan reproduktif. Orang dewasa awal diharapkan memainkan peranan baru seperti peran suami atau istri, orang tua dan mencari nafkah dan mengembangkan sikap-sikap baru, keinginan-keinginan dan nilai-nilai baru sesuai dengan tugas baru [6].

\section{II.4 Kecemasan Sosial}

Kecemasan sosial adalah ketakutan berlebih dan munculnya perasaan tertekan terhadap lingkungan sekitar. Perasaan tidak nyaman ini umumnya menimbulkan gejalagejala fisikologis.

\section{II.5 Social Anxiety Scales for Social Media User \\ (SAS-SMU)}

Social Anxiety Scale for Social Media Users (SASSMU) merupakan sebuah penelitian tentang perilaku manusia dan komputer yang dilakukan oleh Yunus Akis, Zafer Kadirhan dan Mustafa Sat, ketiganya mahasiswa dari Middle East Technical University, Departemen Pendidikan Komputer dan Teknologi Instruksional Turki. skala ini mengGambarkan proses pengembangan dan validasi skala kecemasan sosial multidimensi untuk pengguna media sosial (SAS-SMU) yang dapat digunakan untuk menilai kecemasan sosial yang timbul dari media sosial. Penelitian ini dilakukan dalam dua tahap. Pada tahap pertama daya yang dikumpulkan dari 174 siswa digunakan untuk memberikan bukti validitas dan keandalan strukstur dan dimensi dasarnya. Pada tahap kedua, data dikumpulkan dari 510 mahasiswa digunakan untk mengkonfirmasi struktur empat faktor dari SAS-SMU.
Skala ini digunakan untuk memberikan bukti validasi, keandalan struktur dan dimensi dasar [5]. SAS-SMU memiliki 21 item dari 4 dimensi, diantaranya :

1. Kecemasan membagikan konten (Shared Content Anxiety) (7 item) :

Dimensi ini mengacu pada kecemasan sosial yang berasal dari bebagi konten oleh individu itu sendiri atau oleh orang lain yang berkaitan dengan mereka di platform media sosial. 7 item kecemasan membagikan konten sebagai berikut :

- Saya merasa cemas orang lain menganggap tindakan saya canggung

- Saya khawatir ditertawakan oleh orang lain atas konten yang telah saya bagikan

- Saya khawatir dengan konten yang saya bagikan tidak disukai orang lain.

- Saya takut teman dekat saya tidak akan menyukai perilaku saya.

- Saya akan merasa tidak nyaman saat teman-teman saya mengungkapkan ketidaksukaan mereka terhadap konten yang telah saya bagikan.

- Saya khawatir orang lain tidak menyukai perilaku saya

- Saya khawatir diberi penilaian tentang konten yang saya bagikan oleh teman-teman saya di hadapan orang lain.

2. Kecemasan terhadap data pribadi (Privacy Concern Anxiety) (5 item) :

Dimensi ini mengacu pada kecemasan sosial yang timbul dari kemungkinan mengungkapkan dan berbagi mengenai informasi pribadi di platform media sosial. 5 item kecemasan terhadap data pribadi sebagai berikut :

- Saya merasa cemas orang lain mungkin memperoleh informasi pribadi saya.

- Saya merasa cemas jika informasi pribadi saya dibagikan secara terbuka

- Saya merasa khawatir jika ruang pribadi saya diakses tanpa persetujuan saya.

- Saya merasa cemas tentang bagaimana perusahaan media sosial atau eksekutif menangani kebijakan privasi terkait kehidupan pribadi saya.

3. Kecemasan interaksi (Interaction Anxiety) (6 item) :

Dimensi ini mengacu pada kecemasan sosial yang berasal dari interaksi dan komunikasi dengan seseorang, terutama mereka yang baru ditemui di platform media sosial. 6 item kecemasan interaksi sebagai berikut :

- Saya merasa cemas saat berbicara dengan orang yang baru saja saya temui.

- $\quad$ Saya merasa gugup saat berbicara dengan orang yang saya tidak tahu betul.

- Saya merasa gelisah saat membuat teman baru.

- Saya merasa tegang saat bertemu seseorang untuk pertama kalinya.

- Saya takut berinteraksi dengan orang lain.

- Saya merasa gugup saat harus berbicara dengan orang lain tentang diri saya sendiri.

4. Kecemasan evaluasi diri (Self-Evaluation Anxiety) (3 item) :

Dimensi ini mengacu pada kecemasan sosial yang berasal dari cara seseorang mengevaluasi dan memandang dirinya sendiri karena apa yang dipikirkan orang lain tentang dirinya di platform media sosial. 3 item kecemasan evaluasi diri sebagai berikut : 
- Saya merasa cemas membuat kesan negatif pada orang

- Saya kahawatir orang berpikiran buruk tentang saya.

- Saya merasa cemas karena tidak bisa memenuhi harapan orang.

Skala ini telah diuji dan menghasilkan bukti yang valid bahwa skala 21 item dari 4 dimensi dapat digunakan untuk menilai kecemasan sosial seseorang sebagai pengguna media sosial.

\section{METODOLOGI PENELITIAN}

\section{III.1 Lokasi dan waktu penelitian}

Penelitian ini dilakukan pada pengguna aktif Facebook dan Instagram selama satu tahun. Masing-masing akan diambil dengan cara menyebar kuesioner menggunakan selebaran disalah satu Perguruan Tinggi di Sulawesi Utara tepatnya di Universitas Sam Ratulangi dan di Media Sosial menggunakan Google Form. Penelitian ini dikhususkan untuk dewasa awal berusia 18 sampai dengan 40 tahun. Dengan objek penelitian akan diambil sejumlah sampel, dan waktu penelitian ini berlangsung mulai dari 1 november 2017 sampai dengan 4 desember 2017.

\section{III.2 Kerangka pikir}

Kerangka pikiran merupakan alur pikir penulis yang dijadikan sebagai skema pemikiran atau dasar-dasar pemikiran untuk memperkuat idikator yang melatar belakangi penelitian ini. Dalam kerangka pemikiran ini peneliti akan mencoba menjelaskan masalah pokok penelitian.

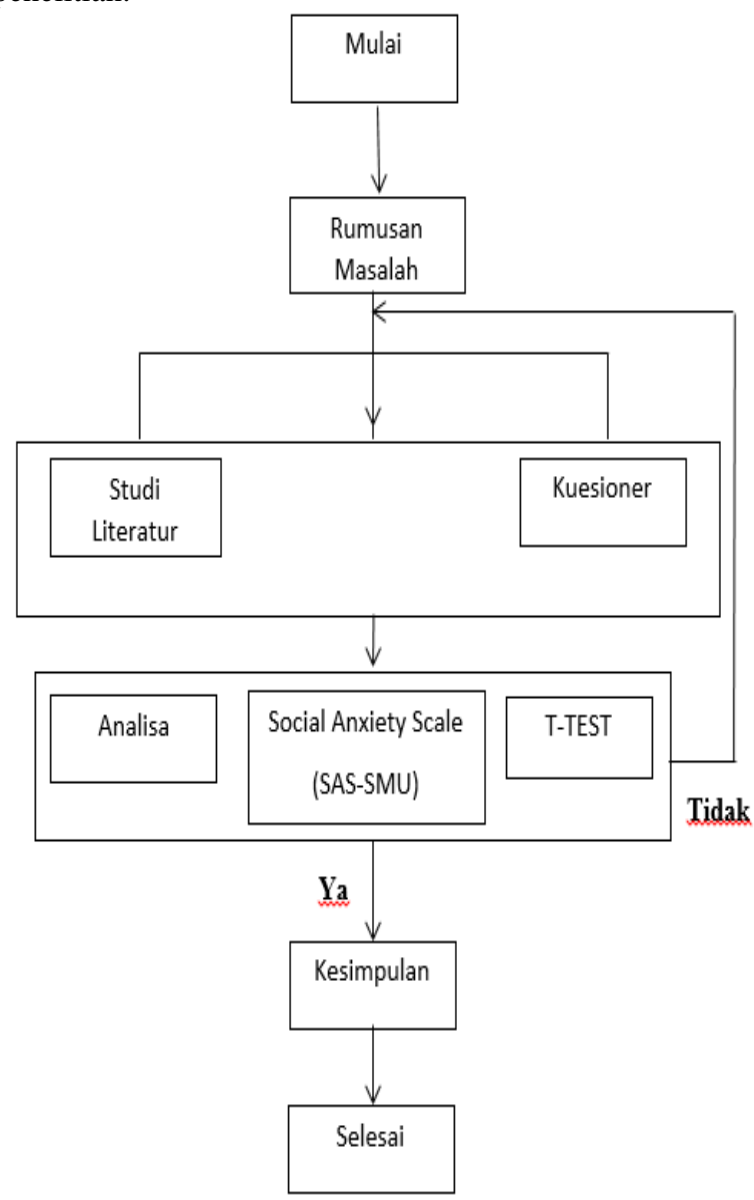

Gambar 1. Kerangka pikir
III.3 Metode pengumpulan data

Metode yang digunakan dalam pengumpulan data yaitu sebagai berikut :

\section{III.3.1 Data Primer}

Data primer diambil dari hasil kuesioner yang diisi oleh pengguna aktif Facebook dan Instagram selama satu tahun terakhir.

\section{III.3.2 Data Sekunder}

Data sekunder diambil dari studi literatur yang akan digunakan sebagai referensi dalam proses validasi skala

\section{III.3.3 Teknik Pengambilan Data}

a. Metode Pustaka

Dalam penelitian ini penulis menggunakan metode pustaka untuk menunjang penelitian ini, diantaranya mencari informasi melalui buku-buku, jurnal, karya ilmiah dll.

\section{b. Kuesioner}

Pengumpulan data yang diutamakan dengan penelitian ini adalah pengumpulan data menggunakan kuesioner. Dimana setiap responden diberikan sejumlah pertanyaan yaitu pertanyaan skala 21 item. Pada setiap jawaban yang diberikan responden akan menjadi acuan untuk melakukan analisa terhadap tingkat kecemasan sosial pengguna Facebook.

\section{III.4 Instrumen penelitian}

Metode pengumpulan data yang digunakan adalah menggunakan skala Sosial Anxiety Scale - Social Media Users (SAS-SMU). Jenis skala yang digunakan pada penelitian ini adalah skala Likert dengan lima alternatif jawaban Tidak Pernah (TP), Jarang (J), Kadang-kadang (KK), Sering (S) dan Selalu (S).

\section{III.4.1 Deskripsi objek}

a. Populasi

Populasi dalam penelitian ini adalah pengguna aktif Facebook dan Instagram satu tahun terakhir berusia dewasa awal dari 18 sampai dengan 40 tahun.

b. Sampel

Sampel dalam penelitian ini pengguna aktif Facebook dan Instagram berusia Dewasa Awal yang aktif selama satu tahun terakhir. Kriteria subjek yang dipilih adalah laki-laki dan perempuan yang tergolong dalam usia dewasa awal. Peneliti membatasi subjek berdasarkan pada rentang usia 18-40 tahun. Hurlock (1996) menetapkan masa dewasa awal dimulai pada umur 18 tahun sampai kira-kira umur 40 tahun. Peneliti memilih subjek dewasa awal karena menurut Hurlock (1996) mengatakan bahwa masa dewasa awal merupakan perode penyesuaian diri terhadap pola-pola kehidupan baru dan harapan-harapan sosial baru. Sehingga peneliti berasumsi bahwa dewasa awal lebih rentan mengalami kecemasan sosial, sehingga lebih sering menggunakan Facebook dan Instagram.

\section{III.5 Analisa data}

Analisa data adalah kegiatan analis mengkategorikan data untuk mendapatkan pola hubungan dan mengartikan apa yang bermakna, dan menyampaikan hasil dari analis data tersebut. 


\section{HASIL DAN PEMBAHASAN}

Penelitian ini adalah jenis penelitian deskriptif yang berupaya untuk mengungkapkan suatu permasalahan yang ada berdasarkan data faktual, yaitu dengan menyajikan data berdasarkan hasil eksplorasi data di lapangan dan di media sosial. Pengumpulan data dilakukan dengan membagikan selebaran kuesioner kepada responden dan meneyebarkan kuesioner online di media sosial. Selain itu penelitian ini juga ingin mengetahui tingkat kecemasan sosial pengguna media sosial khususnya pengguna Facebook dan Instagram. Data yang diperoleh dalam penelitian ini berdasarkan kuesioner yang dibagikan kepada responden yang berusia 18 sampai dengan 40 tahun. Penyajian data ini untuk menjawab pertanyaan sesuai penelitian, data penelitian ini mengacu pada rumusan masalah.

IV.1 Social Anxiety Scales for Social Media User (SASSMU)

Dari hasil data yang dikumpulkan melalui kuesioner dapat dilihat pada Gambar grafik empat dimensi, pertanyaan dalam kuesioner terdiri dari 21 pertanyaan yang telah digabungkan dari 4 dimensi yaitu, Kecemasan membagikan konten (7 item ), kecemasan terhadap data pribadi (5 item), kecemasan interaksi (6 item) dan kecemasan evaluasi diri (3 item). Penelitian ini melakukan perbandingan data antara pengguna Facebook dan Instagram untuk mengetahui apakah kecemasan sosial pengguna Facebook dan Instagram berbeda atau tidak, jadi data yang dikumpulkan berdasarkan pilihan jawaban dari hasil pengisian langsung oleh responden pengguna aktif Facebook dan pengguna aktif Instagram. Gambar 2 grafik hasil dari data kecemasan membagikan konten pengguna Facebook dan pengguna Instagram, yaitu :

\section{IV.1.1 Kecemasan membagikan konten}

a. Pada dasarnya pengguna Facebook dan Instagram memiliki peluang yang sama untuk membagikan konten, karena Facebook dan Instagram memiliki fitur membagikan konten sehingga user pengguna Facebook dan Instagram tidak memiliki perbedaan kecemasan sosial dalam hal membagikan konten.

b. Dilihat dari hasil data yang dikumpulkan, responden lebih banyak memilih jawaban tidak pernah pada kuesioner yang telah dibagikan. Dapat disimpulkan bahwa pengguna Facebook dan Instagram tidak mengalami kecemasan sosial dalam hal kecemasan membagikan konten.

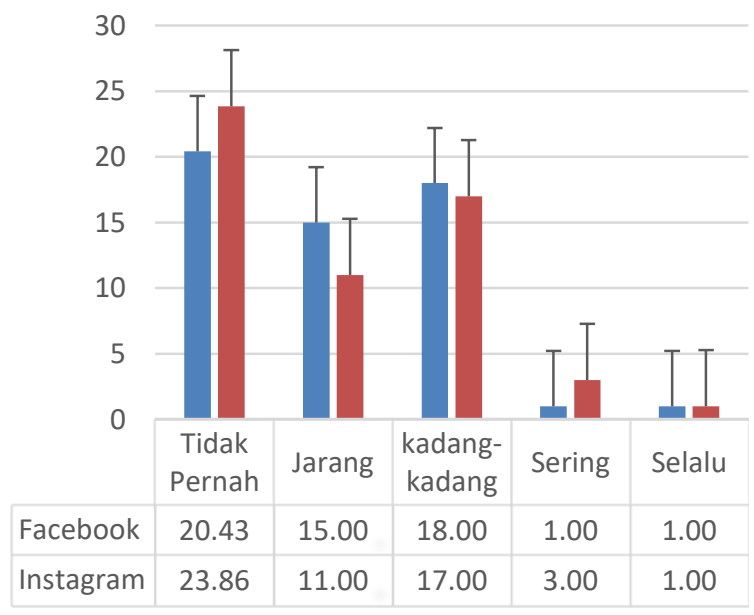

Gambar 2. Grafik kecemasan membagikan konten c. Pengguna Instagram lebih banyak memilih tidak pernah dibandingkan pengguna Facebook, karena dari segi keamanan untuk membagikan konten, Facebook memiliki fitur menandai konten yang bebas dilakukan pengguna lain untuk menandai akun miliknya tanpa izin user. berbeda dengan Instagram, fitur menandai pada Instagram hanya bisa dilakukan oleh user dan pengguna lain tidak dapat menandai akun miliknya kedalam konten yang user bagikan.

Berdasarkan fitur yang berkaitan dalam hal membagikan konten orang lain, Facebook juga tidak memiliki keamanan dalam membagikan konten, sehingga konten yang user kirim pada platform dapat disebar luaskan oleh pengguna Facebook lainnya. Sedangkan Instagram tidak menyediakan fitur untuk membagikan konten orang lain, sehingga pengguna Instagram lebih merasa aman untuk membagikan konten miliknya pada platform Instagram.

\section{IV.1.2 Kecemasan terhadap data pribadi}

Gambar 3 grafik hasil dari data kecemasan terhadap data pribadi pengguna Facebook dan pengguna Instagram, yaitu:

a. Pada dasarnya Facebook dan Instagram memiliki fitur menyediakan informasi data diri, namun ada beberapa perbedaan informasi data diri pada Facebook dan Instagram. Berdasarkan data yang dikumpulkan dari responden pengguna Facebook dan Instagram, responden lebih banyak memilih jawaban kadang-kadang pada dimensi kecemasan terhadap data diri. Dapat disimpulkan bahwa pengguna Facebook dan Instagram tidak mengalami kecemasan sosial dalam hal kecemasan terhadap data pribadi.

b. Ada perbedaan jawaban pada dimensi kecemasan terhadap data pribadi yang memilih jawaban tidak pernah, dimana pengguna Instagram tidak pernah merasa cemas dibandingkan pengguna Facebook. Karena fitur informasi data diri pada Facebook lengkap dan terkesan lebih terbuka dibandingkan Instagram. Facebook dapat menampilkan semua informasi data diri meskipun akun dalam keadaan privasi. Sedangkan Instagram hanya menampilkan nama dan foto profil user.

c. Facebook juga menyediakan pengingat untuk informasi hari ulang tahun user pengguna Facebook pada pengguna lainnya, sedangkan Instagram tidak memiliki fitur informasi hari ulang tahun untuk pengguna Instagram. Sehingga kadang-kadang membuat user pengguna Facebook cemas dalam hal data pribadi.

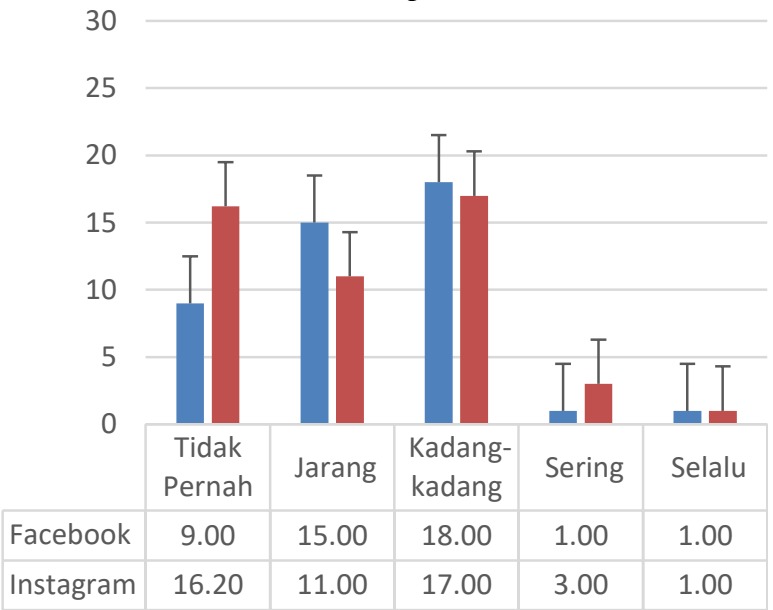

Gambar 3. Grafik kecemasan terhadap data pribadi 
IV.1.3 Kecemasan interaksi

Gambar 4 grafik hasil dari data kecemasan interaksi pengguna Facebook dan pengguna Instagram, yaitu :

a. Pada dasarnya Facebook dan Instagram memiliki fitur mengirim pesan, siaran langsung, komentar dan tanggapan, namun ada beberapa perbedaan pada fitur Facebook dan Instagram.

b. Berdasarkan data yang telah dikumpulkan dari responden pengguna Facebook dan Instagram, tidak ada perbedaan antara Facebook dan Instagram dalam hal kecemasan interaksi. Responden Facebook lebih banyak memilih tidak pernah, jarang dan kadangkadang, meskipun ada perbedaan jawaban jarang pada pengguna Facebook dan Instagram, namun tidak mempengaruhi kecemasan interaksi. Sehingga dapat disimpulkan bahwa responden pengguna Facebook dan Instagram cenderung terbuka dan tidak khawatir pada interaksi.

c. Pada dasarnya Facebook dan Instagram memiliki fitur yang sama pada umumnya, Facebook dan Instagram sama-sama menyediakan fitur untuk berinteraksi dengan pengguna lain. Namun fitur- fitur pada Facebook lebih banyak memiliki fungsi daripada fitur pada Instagram. Pengguna Facebook dapat mengirimkan file dokumen dan panggilan video menggunakan fitur messenger, sedangkan Instagram tidak dapat mengirim file dan melakukan panggilan video pada direct message, sehingga pengguna Facebook lebih nyaman berinteraksi dan tidak pernah merasa cemas.

d. Fitur siaran langsung, komentar dan tanggapan atau like pada Facebook dan Instagram juga tidak mempengaruhi kecemasan, namun ada sedikit perbedaan diantaranya. Siaran langsung pada Facebook memiliki enam pilihan tanggapan ekspresi dan tidak dapat mengundang pengguna lain untuk siaran langsung secara bersamaan pada satu layar, sedangkan Instagram hanya memiliki satu simbol tanggapan ekspresi dan dapat mengundang pengguna lain untuk siaran langsung secara bersamaan dalam satu layar.

e. Fitur komentar dan menyukai pada Facebook dan Instagram juga tidak mempengaruhi kecemasan interaksi, karena fitur ini membantu pengguna Facebook dan Instagram untuk memberikan tanggapan pada konten yang dibagikan user melalui komentar dan like.

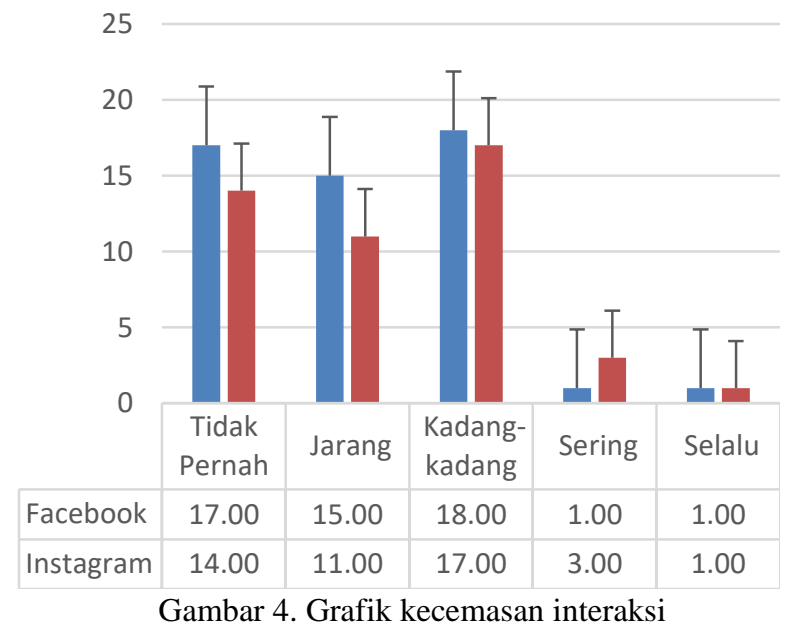

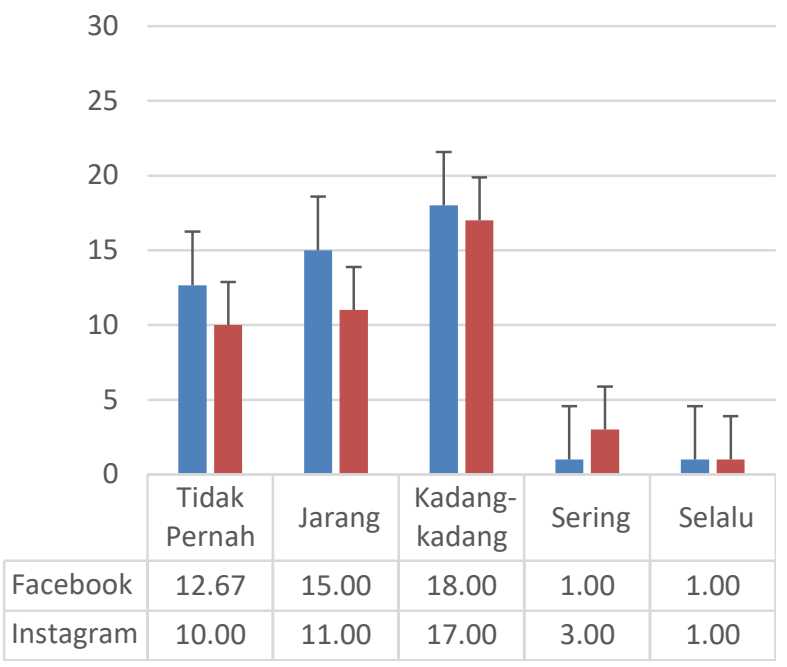

Gambar 5. Grafik kecemasan evaluasi diri

\section{IV.1.4 Kecemasan evaluasi diri}

Gambar 5 grafik hasil dari data kecemasan evaluasi diri pengguna Facebook dan pengguna Instagram, yaitu :

a. Pada dasarnya Facebook dan Instagram memiliki fitur membagikan konten atau mengirimkan konten, namun ada beberapa perbedaan pada fitur Facebook dan Instagram.

b. Berdasarkan data yang telah dikumpulkan dari responden pengguna Facebook dan Instagram, responden lebih banyak memilih jawaban kadangkadang pada pilihan jawaban dikuesioner. Sehingga dapat disimpulkan pengguna Facebook dan Instagram kadang-kadang mengalami kecemasan terhadap konten yang mereka bagikan pada platform Facebook dan Instagram. Namun responden pengguna Facebook dan Instagram lebih cenderung tidak mengalami kecemasan dalam membagikan konten.

c. Pada dasarnya Facebook dan Instagram memiliki fitur yang sama dalam hal membagikan konten, namun letak perbedaan Facebook dan Instagram saat membagikan konten yaitu. Facebook dapat mengirim berbagai jenis konten pada platform, sedangkan Instagram hanya dapat mengirim foto dan video saja pada platform. Responden pengguna Facebook dan Instagram lebih banyak tidak pernah merasa cemas pada konten yang mereka bagikan. Responden pengguna Facebook dan Instagram juga cenderung terbuka dan tidak khawatir pada tanggapan orang lain atas konten yang mereka bagikan.

IV.2 Hasil T-TEST pengguna Facebook dan Instagram IV.2.1 Hasil T-TEST kecemasan membagikan konten

Jumlah responden yang sudah ditambahkan dari setiap pertanyaan dijumlahkan berdasarkan poin 1-5 lalu dibagi 50 dan hasil nilai rata-rata. Setelah itu diuji menggunakan TTEST pada Microsoft excel. Fungsi T-Test adalah sebagai uji komparasi antara dua sampel bebas. Tes ini diterapkan jika analisis data bertujuan untuk mengetahui apakah dua kelompok sampel berbeda dalam variable tertentu. 
a. Hasil T-TEST kecemasan membagikan konten

Gambar pada Tabel 2 merupakan hasil analisis dimensi kecemasan membagikan konten pada Facebook dan Instagram. Hasil dari data pengguna Facebook dan pengguna Instagram yang telah dites menggunakan T-Test, menunjukkan bahwa hasilnya tidak signifikan. Responden pengguna Facebook dan Instagram tidak mengalami kecemasan dalam hal membagikan konten.

Tabel 2. T-test skala 1 pengguna Facebook dan Instagram

\begin{tabular}{|c|c|c|}
\hline \multicolumn{3}{|c|}{ Skala 1} \\
\hline Facebook & Instagram & T-Test \\
\hline 0.3 & 0.34 & \\
\hline 0.6 & 0.44 & \\
\hline 1.08 & 1.02 & \\
\hline 0.08 & 0,32 & \\
\hline 0.1 & 0.1 & \\
\hline 0.432 & 0.444 & 0.480872144 \\
\hline Facebook & Instagram & T-Test \\
\hline 0.5 & 0.4 & \\
\hline 0.4 & 0.4 & \\
\hline 0.66 & 0.84 & \\
\hline 0.32 & 0.4 & \\
\hline 0 & 0.1 & \\
\hline 0.376 & 0.092 & 0.156741649 \\
\hline Facebook & Instagram & T-Test \\
\hline 0.38 & 0.48 & \\
\hline 0.44 & 0.44 & \\
\hline 0.84 & 0.66 & \\
\hline 0.4 & 0.24 & \\
\hline 0.1 & 0.1 & \\
\hline 0.432 & 0.384 & 0.381148206 \\
\hline Facebook & Instagram & T-Test \\
\hline 0.42 & 0.58 & \\
\hline 0.48 & 0.2 & \\
\hline 0.6 & 0.6 & \\
\hline 0.24 & 0.16 & \\
\hline 0.4 & 0.4 & \\
\hline 0.428 & 0.388 & 0.361617101 \\
\hline Facebook & Instagram & T-Test \\
\hline 0.42 & 0.52 & \\
\hline 0.52 & 0.6 & \\
\hline 0.78 & 0.3 & \\
\hline 0.16 & 0.08 & \\
\hline 0.1 & 0.3 & \\
\hline 0.396 & 0.36 & 0.410629422 \\
\hline Facebook & Instagram & T-Test \\
\hline 0.42 & 0.38 & \\
\hline 0.36 & 0.52 & \\
\hline 0.78 & 0.54 & \\
\hline 0.32 & 0.32 & \\
\hline 0.3 & 0.5 & \\
\hline 0.436 & 0.452 & 0.437423937 \\
\hline Facebook & Instagram & T-Test \\
\hline 0.42 & 0.5 & \\
\hline 0.48 & 0.52 & \\
\hline 0.72 & 0.48 & \\
\hline 0.4 & 0.08 & \\
\hline 0 & 0.3 & \\
\hline 0.404 & 0.376 & 0.42486438 \\
\hline
\end{tabular}

b. Hasil T-TEST kecemasan terhadap data pribadi

Gambar pada Tabel 3 merupakan hasil analisis dimensi kecemasan terhadap data pribadi pada Facebook dan Instagram. Hasil dari data pengguna Facebook dan pengguna Instagram yang telah dites menggunakan T-Test, menunjukkan bahwa hasilnya tidak signifikan. Responden pengguna Facebook dan Instagram tidak mengalami kecemasan terhadap data pribadi.

Tabel 3. T-test skala 2 pengguna Facebook dan Instagram

\begin{tabular}{|c|c|c|}
\hline \multicolumn{3}{|c|}{ Skala 2} \\
\hline Facebook & Instagram & T-Test \\
\hline 0.22 & 0.34 & \\
\hline 0.24 & 0.32 & \\
\hline 1.08 & 0.72 & \\
\hline 0.96 & 0.64 & \\
\hline 0.3 & 0.5 & \\
\hline 0.56 & 0.504 & 0.395906207 \\
\hline Facebook & Instagram & T-Test \\
\hline 0.18 & 0.24 & \\
\hline 0.12 & 0.4 & \\
\hline 1.26 & 0.72 & \\
\hline 0.96 & 0.64 & \\
\hline 0.5 & 0.8 & \\
\hline 0.604 & 0.56 & 0.430941367 \\
\hline Facebook & Instagram & T-Test \\
\hline 0.08 & 0.26 & \\
\hline 0.48 & 0.36 & \\
\hline 1.08 & 0.6 & \\
\hline 0.56 & 0.72 & \\
\hline 0.9 & 0.9 & \\
\hline 0.62 & 0.568 & 0.40508451 \\
\hline Facebook & Instagram & T-Test \\
\hline 0.14 & 0.24 & \\
\hline 0.36 & 0.2 & \\
\hline 0.72 & 0.96 & \\
\hline 0.8 & 0.64 & \\
\hline 1.2 & 0.9 & \\
\hline 0.644 & 0.588 & 0.411872349 \\
\hline Facebook & Instagram & T-Test \\
\hline 0.28 & 0.44 & \\
\hline 0.2 & 0.28 & \\
\hline 1.02 & 0.78 & \\
\hline 0.24 & 0.4 & \\
\hline 0.6 & 0.3 & \\
\hline 0.468 & 0.44 & 0.439919591 \\
\hline
\end{tabular}


c. Hasil T-TEST kecemasan interaksi

Gambar pada Tabel 4 merupakan hasil analisis dimensi kecemasan interaksi pada Facebook dan Instagram. Hasil dari data pengguna Facebook dan pengguna Instagram yang telah dites menggunakan T-Test, menunjukkan bahwa hasilnya tidak signifikan. Responden pengguna Facebook dan Instagram tidak mengalami kecemasan dalam hal interaksi.

Tabel 4. T-test skala 3 pengguna Facebook dan Instagram

\begin{tabular}{|c|c|c|}
\hline \multicolumn{3}{|c|}{ Skala 3} \\
\hline Facebook & Instagram & T-Test \\
\hline 0.32 & 0.24 & \\
\hline 0.56 & 0.48 & \\
\hline 0.84 & 0.96 & \\
\hline 0.4 & 0.64 & \\
\hline 0.1 & 0.2 & \\
\hline 0.444 & 0.504 & 0.377905495 \\
\hline Facebook & Instagram & T-Test \\
\hline 0.26 & 0.2 & \\
\hline 0.68 & 0.44 & \\
\hline 0.72 & 1.2 & \\
\hline 0.48 & 0.32 & \\
\hline 0.2 & 0.5 & \\
\hline 0.468 & 0.532 & 0.381031115 \\
\hline Facebook & Instagram & T-Test \\
\hline 0.44 & 0.38 & \\
\hline 0.56 & 0.68 & \\
\hline 0.6 & 0.6 & \\
\hline 0.32 & 0.32 & \\
\hline 0 & 0 & \\
\hline 0.384 & 0.396 & 0.471180505 \\
\hline Facebook & Instagram & T-Test \\
\hline 0.22 & 0.16 & \\
\hline 0.56 & 0.68 & \\
\hline 0.96 & 1.02 & \\
\hline 0.72 & 0.48 & \\
\hline 0 & 0.2 & \\
\hline 0.492 & 0.508 & 0.473642673 \\
\hline Facebook & Instagram & T-Test \\
\hline 0.52 & 0.44 & \\
\hline 0.48 & 0.68 & \\
\hline 0.24 & 0.48 & \\
\hline 0 & 0.24 & \\
\hline 0 & 0 & \\
\hline 0.248 & 0.368 & 0.23855911 \\
\hline Facebook & Instagram & T-Test \\
\hline 0.28 & 0.22 & \\
\hline 0.76 & 0.6 & \\
\hline 0.66 & 0.78 & \\
\hline 0.24 & 0.72 & \\
\hline 0.3 & 0.2 & \\
\hline 0.448 & 0.504 & 0.371105207 \\
\hline
\end{tabular}

d. Hasil T-TEST kecemasan evaluasi diri

Gambar pada Tabel 5 merupakan hasil analisis dimensi kecemasan evalusi diri pada Facebook dan Instagram. Hasil dari data pengguna Facebook dan pengguna Instagram yang telah dites menggunakan T-Test, menunjukkan bahwa hasilnya tidak signifikan. Responden pengguna Facebook dan Instagram tidak mengalami kecemasan evaluasi diri.

Tabel 5. T-test skala 4 pengguna Facebook dan Instagram

\begin{tabular}{|c|c|c|}
\hline \multicolumn{3}{|c|}{ Skala 4 } \\
\hline Facebook & Instagram & T-Test \\
\hline 0.2 & 0.16 & \\
\hline 0.4 & 0.36 & \\
\hline 0.66 & 0.84 & \\
\hline 1.04 & 0.96 & \\
\hline 0.4 & 0.7 & $\mathbf{0 . 3 8 3 2 3 3 1 2 9}$ \\
\hline $\mathbf{0 . 5 4}$ & $\mathbf{0 . 6 0 4}$ & T-Test \\
\hline Facebook & Instagram & \\
\hline 0.16 & 0.24 & \\
\hline 0.32 & 0.44 & \\
\hline 0.66 & 0.9 & $\mathbf{0 . 4 8 7 8 7 7 8 6 3}$ \\
\hline 1.36 & 0.56 & T-Test \\
\hline 0.1 & 0.5 & \\
\hline $\mathbf{0 . 5 2}$ & $\mathbf{0 . 5 2 8}$ & \\
\hline Facebook & Instagram & \\
\hline 0.2 & 0.2 & $\mathbf{0 . 4 1 5 9 9 9 1 2}$ \\
\hline 0.4 & 0.36 & \\
\hline 0.84 & 1.14 & \\
\hline 0.88 & 0.56 & \\
\hline 0.2 & 0.5 & \\
\hline $\mathbf{0 . 5 0 4}$ & $\mathbf{0 . 5 5 2}$ & \\
\hline & & \\
\hline
\end{tabular}

\section{PENUTUP}

\section{V.1 Kesimpulan}

Berdasarkan penelitian yang dilakukan pada media sosial khususnya pengguna Facebook dan Instagram untuk mengetahui tingkat kecemasan sosial yang dialami pengguna berusia dewasa awal, maka dapat diambil kesimpulan dari tugas Akhir ini adalah:

- Dari hasil data pengguna Facebook dan Instagram yang dikumpulkan, data menunjukkan ada sedikit perbedaan antara pengguna Facebook dan pengguna Instagram. Namun dari hasil analisis menggunakan instrumen Social Anxiety Scales for Social Media User (SAS-SMU), tingkat kecemasan sosial pengguna Facebook dan Instagram sama dan tidak ada perbedaan.

\section{V.2 Saran}

Untuk pengembangan lebih lanjut maka penulis butuh memberikan saran yang sangat bermanfaat dan dapat membantu menunjang untuk kedepannya lagi yang lebih baik, yaitu :

1. Penelitian selanjutnya, disarankan untuk menggunakan subjek dengan rentang usia yang lebih luas supaya lebih sesuai dengan fungsinya.

2. Penelitian selanjutnya yang tertarik untuk meneliti kecemasan sosial pada pengguna Facebook dan Instagram dapat memperhatikan faktor lain, seperti kecemasan sosial berdasarkan jenis kelamin dan usia. 


\section{DAFTAR REFERENSI}

[1] Wardani Agustin Setyo, 2017. Pengguna Aktif Facebook di Indonesia. http://tekno.liputan6.com/read/3057940/Faceboo k-kini-punya-115-juta-pengguna-aktif-diindonesia.

[2] Perguruan Tinggi Indonesia Mandiri, 2017. Pengguna Instagram se-Asia Pasifik yaitu Indonesia, http://www.imandiri.id/penggunainstagram-terbesar-se-asia-pasifik-yaituindonesia/.

[3] Sopiah Nyimas, 2013. Seminar Nasional Aplikasi Teknologi Informasi (SNATI), Faktor-Faktor yang Memperngaruhi Penggunaan Media Facebook, Fakultas Ilmu Komputer Universitas Bina Darma, Palembang.

[4] Arslan Mailanto, 2016. Pengguna Instagram Terbanyak di Indonesia mencapai $89 \%$. https://techno.okezone.com/read/2016/01/14/207/ 1288332/pengguna-instagram-di-indonesiaterbanyak-mencapai-89.

[5] Alkış Yunus, et al, 2017. Computers in Human Behavior. Development and Validation of Social Anxiety Scale for Social Media Users, Middle East Technical University, Turkey.

[6] Hurlock, E. B. (1994). Psikologi Perkembangan, Suatu Pendekatan Sepanjang Rentang Kehidupan Erlangga, Jakarta.

\section{SEKILAS TENTANG PENULIS}

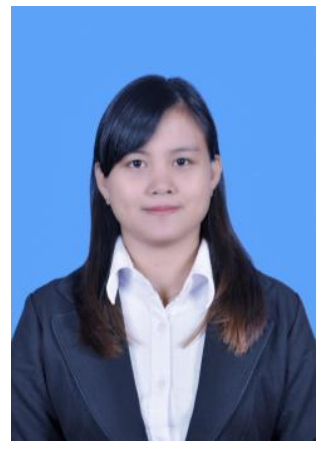

Saya bernama Fitria Herman dan merupakan anak ke-5 dari 5 bersaudara dari pasangan Herman Ibrahim dan Murni Sampe, lahir di Palu pada tanggal 2 Maret 1994. Asal daerah Tarakan, Kalimantan Utara.

Saya mulai menempuh pendidikan di sekolah dasar SDN 029 Tarakan (2000 - 2007). Kemudian melanjutkan studi tingkat pertama di SMPN 8

Tarakan (2007 - 2010) dan selanjutnya saya menempuh pendidikan tingkat atas di SMKN 2 Tarakan (2010 - 2013).

Setelah itu, di tahun 2013 saya melanjutkan pendidikan ke salah satu perguruan tinggi yang berada di Manado yaitu Universitas Sam Ratulangi Manado, dengan mengambil Program Studi S-1 Teknik Informatika di Jurusan Elektro Fakultas Teknik. 